\title{
Selection of a Combined Heat and Power (CHP), and CHP Generation Compared to Buying of Electrical Power from the National Grid and Separate Thermal Heat Production
}

\author{
Moses Otieno Apunda ${ }^{1 *}$, Benard Oloo Nyangoye ${ }^{2}$ \\ ${ }^{1}$ University of Leeds, Leeds, United Kingdom \\ ${ }^{2}$ Masinde Muliro University of Science and Technology, Kakamega, \\ Kenya
}

\section{OPEN ACCESS}

Citation: Moses Otieno Apunda; Benard Oloo Nyangoye (2017) Selection of a Combined Heat and Power (CHP), and CHP Generation Compared to Buying of Electrical Power from the National Grid and Separate Thermal Heat Production Open Science Journal 2(3).

Received: $21^{\text {st }}$ July 2017

Accepted: $8^{\text {th }}$ August 2017

Published: $29^{\text {th }}$ August 2017

Copyright:@ 2016 This is an open access article under the terms of the Creative Commons

Attribution License, which permits unrestricted use, distribution, and reproduction in any medium, provided the original author and source are credited.

Funding: The author(s) received no specific funding for this work.

Competing Interests: The author have declared that no competing interests exists.
*Corresponding Author: Moses Otieno Apunda: mostecheng@gmail.com

\begin{abstract}
In this work, Combined Heat and Power (CHP) is critically discussed and its application analytically compared with alternative energy source.CHP efficiency was first compared with the conventional generation and realised that, for equivalent heat and power production, CHP exhibits a higher efficiency than conventional generation. For example, energy input of $215 \mathrm{~J}$ and 170J for Conventional generation and CHP respectively produces equal amounts of heat and power with CHP having efficiency of $76.5 \%$ which is $16.5 \%$ more efficient than the conventional type with $60 \%$. Factors influencing the choice of a CHP plant such as financial considerations, Environmental and Compliance considerations, Site Specific considerations and Technical parameters Considerations are vastly discussed. Since the choice of a CHP and it's application depends on the type of the prime mover, different types of the CHPs and their applications were then discussed to understand their working principles and the choice of the fuel used. Two typical case scenarios were analytically compared to look into the most economical way of acquiring heat and power for a plant. Cogeneration (A) was compared with buying of electrical power from the national grid and at the same time producing thermal energy in the plant using natural gas fired boiler(B). From cost analysis of the case scenarios, it is confirmed that cogeneration (A) is the most economical aspect compared to alternative B. Finally, the advantages and the disadvantages of a CHP are explored.
\end{abstract}

Keywords: Cogeneration, Efficiency, Energy, Turbine, Heat, Power 


\section{Introduction}

Combined Heat and Power is the simultaneous production and utilisation of heat and electricity from a single source of fuel (Sanaye et al., 2008). Basically, CHP can convert $75-85 \%$ of fuel energy to useful energy but currently, the modern type CHP can have a conversion efficiency of over $90 \%$ ( Vasebi et al., 2007).Minimum losses are incurred with this technology since the end users are sited near the production site. CHP consists of:-Driving system (Engine), Generator for electricity production, heat recovery system and Control system. Prime mover drives the generator to produce the electricity (IEA, 2008). As the prime mover drives the generator, useful energy is recovered. Classification of the CHP units therefore depends on the fuel used, type of application and the prime mover. CHP has got higher efficiency compared to the conventional method of power and heat production which involves separate energy plants with high fuel consumption and a lower efficiency as analysed by USEPA, 2008 on figure 1

Figure 1: Efficiency gain of combined heat and power compared to conventional generation.

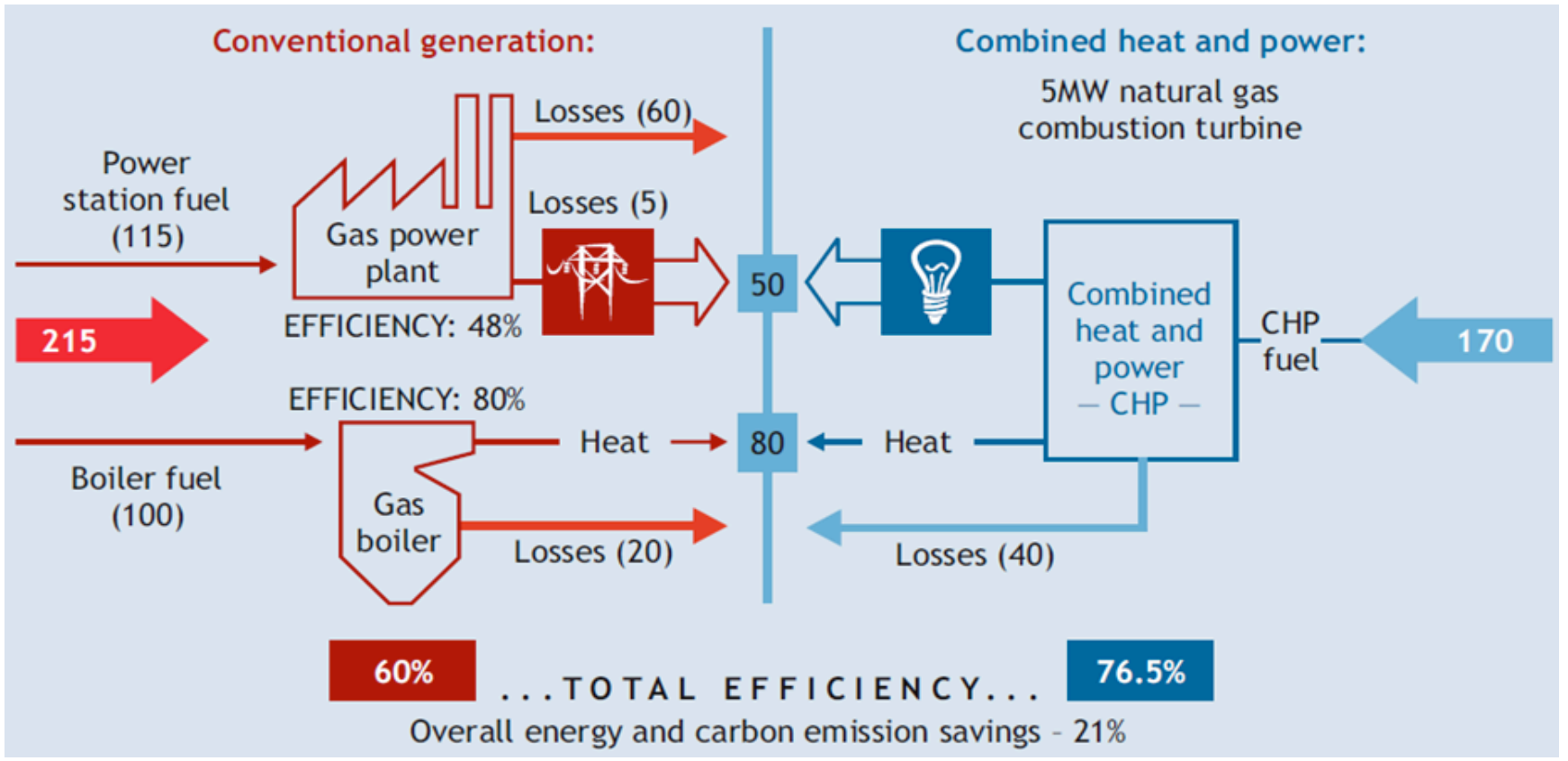

Source: (IEA analysis, USEPA, 2008).

\section{Efficiency of the conventional generation}

\section{Gas power plant efficiency}

Fuel input for the power station=115GJ,

Energy Losses of the Gas power plant $=60 \mathrm{GJ}$

Useful Energy of the Power station= (Fuel Input - Energy Losses $)$

$$
=(115-60),=55 \mathrm{GJ}
$$

Power Generation Efficiency $=($ Useful Energy $/$ Fuel Input $)$ x100\%,

$$
=(55 / 115) \times 100 \%,=48 \%
$$


It is important to take note of gas power plant loss amounting to 5 due to electricity transmission.

\section{Gas boiler efficiency}

Boiler fuel input $=100 \mathrm{GJ}$

Boiler energy losses $=20 \mathrm{GJ}$

Boiler useful energy $=($ Fuel Input - Energy Losses $)$

$$
=(100-20),=80 \mathrm{GJ}
$$

Thermal Heat Efficiency $=($ Useful Energy/Fuel Input) $x 100 \%$, $=(80 / 100) \times 100 \%,=80 \%$

\section{Efficiency of the conventional generation to meet both heat and power}

Total fuel input for Power Station and Boiler=Power station fuel + Boiler fuel

$$
=(115+100),=215 \mathrm{GJ}
$$

Total Energy Losses for power station and the boiler $=(60+5+20),=85 \mathrm{GJ}$

Total Useful Energy= (Total fuel input - Total Energy Losses $)$

$$
=(215-85),=130 \mathrm{GJ}
$$

Efficiency of Conventional Generation $=($ Total Useful Energy/Total Fuel Input $)$ $\mathrm{x} 100 \%$

$$
=(130 / 215) \times 100 \%,=60 \%
$$

\section{Combined heat and power efficiency}

Combined Heat and Power Fuel Input=170GJ

Total Energy Losses $=40 \mathrm{GJ}$

Total Useful Energy $=($ Fuel Input - Total Energy Losses $)$

$$
=(170-40),=130 \mathrm{GJ}
$$

Combined Heat and Power Efficiency = (Total Useful Energy/Total Fuel Input) $\mathrm{x} 100 \%$

$$
=(130 / 170) \times 100 \%,=76.5 \%
$$

In CHP plants, with low fuel use and higher efficiency, the carbon savings is reduced. According to Song et al, 1999, the higher CHP efficiency reduces the system's production cost while ensuring demand of both heat and power are met. It is therefore clear that, from the IEA analysis, USEPA (2008), CHP is the best alternative since it is highly effective with low emissions and low fuel consumption compared to the conventional generation which uses high fuel consumption with low efficiency giving same amount of energy.

\section{CHP Choice Consideration}

The application of the CHP is dependent on the site since the proportion of heat and power required may vary from site to site. CHP is designed to meet the 
demand for which it is intended for and any excess power produced may be sold to the grid and in case there is deficit of the electricity production, the grid can as well supply the site. Thermal energy can as well be exported in case there is surplus. The efficiency of the CHP system is dictated by factors such as fuel and the technology used. Before choosing to install a given type of CHP, it is important to consider factors for its viability in the area. The factors include

(USEPA, 2013; Sanaye et al., 2008):

\section{Financial considerations}

It is wise considering:-

- The upfront capital which is to be used in installing a new CHP and compared to the alternative replacement of an already existing boiler to analyse if the costs can be saved.

- The maintenance and operation costs of the newly to be installed CHP.

- The benefits which comes as a result of maintaining the operations in case there is disruptions from the grid supply e.g. the benefits can be monetary benefits due to continuously giving of services in hospitals, running of data servers and research and development activities.

- To analyse if installing a new CHP will meet an organization's financial target i.e. how long the organization will get back their capital invested (rate of return and return on investment.

- If there is any financial incentive available from any arm of the government such as the state, local authority or Federal authority.

\section{Environmental and compliance considerations}

Include:-

- Legislative air quality requirement compliance from such a particular country.

- The local ordinance requirements such as fire regulations and the building codes.

- Achievement of the organization's goals on sustainability and climate change goals.

- The policies of the state which govern the utilities especially on CHP operation such as the standby charges and the interconnection charges.

\section{Site specific considerations}

\section{(a) The matching of the base electrical load}

Using the historical heat and power demand curve, the minimum electricity demand of the site is analysed before a particular CHP is chosen. This allows plan to be put in place for any deficit of the needed power to be purchased from the utility grid. Also, if the thermal demand exceeds the generation of the CHP, the standby boilers can be used to bridge the gap. As well, if either thermal energy or electricity energy exceeds the site's demand, the surplus can be 
exported to further add to the income of the CHP if local legislation permits for that.

\section{(b) Marching of the base thermal load}

The CHP supplies the minimum thermal requirement to the site. In situations when the demand of heat exceeds the minimum requirement, the standby boilers and heaters are operated to give more heat supply. Here, the prime movers always operate at full load giving electricity at full load. If the electricity demand goes beyond the generated amount, the deficit amount is purchased from the grid while if excess electricity is produced, then, the excess electricity can be sold to the grid if the local law warrants that.

\section{(c) Matching electrical load}

This is a situation whereby the facility doesn't depend on the power utility grid. All the power reserve requirements during both scheduled and unscheduled maintenance are to be incorporated with alternative during planning of the system. Suppose the thermal energy demand is higher than the production, the auxiliary boilers are put in line to give the deficit supply. On contrary, with a lower thermal demand, there will be a waste of thermal energy but it can as well be exported to other nearby facilities.

\section{(d) Matching thermal load}

The generation system is designed to meet the thermal needs of the site at any time and therefore the operation of the prime movers is such to meet the thermal demand always. If high demand of the thermal energy results into surplus electricity, the excess electricity can then be sold to the grid utility if the local legislation warrants for that. As well, if low demand of thermal energy results into the less electricity production, the deficit is compensated by purchasing from national grid.

\section{Technical parameters considerations}

Depending on the type of demand, technical parameters are widely considered to help choose the right prime mover. Some of the key factors considered include:-

\section{(a)Heat to power ratio}

This is critical for CHP to match the need of the facility it is likely to serve. Heat to power ratio is the ratio of thermal energy needed by the consuming facility to the electricity required by the same facility all expressed in the same units of energy such as kilowatt $(\mathrm{kW})$. This is important since every application of CHP have varying heat to power ratio as shown on figure 1 and different prime movers portray different heat to power ratio and efficiency as shown on figure 2 . 
Table 1: Heat to power ratio requirement of certain industries

\begin{tabular}{|c|c|c|c|}
\hline Industry & Minimum & Maximum & Average \\
\hline Breweries & 1.1 & 4.5 & 3.1 \\
\hline Pharmaceuticals & 1.5 & 2.5 & 2.0 \\
\hline Fertilizers & 0.8 & 3.0 & 2.0 \\
\hline Food & 0.8 & 2.5 & 1.2 \\
\hline Paper & 1.5 & 2.5 & 1.9 \\
\hline
\end{tabular}

Source: (E. C. B., 2007)

Table 2: Heat to power ratio, power output and overall efficiency of different CHP systems

\begin{tabular}{|l|c|c|c|}
\hline \multicolumn{1}{|c|}{$\begin{array}{c}\text { Cogeneration } \\
\text { System }\end{array}$} & $\begin{array}{c}\text { Heat-to-power } \\
\text { ratio } \\
\mathbf{k} \mathbf{W}_{\mathbf{t h}} / \mathbf{k} \mathbf{W}_{\mathbf{e}}\end{array}$ & $\begin{array}{c}\text { Power } \\
\text { output(As } \\
\text { percent of fuel } \\
\text { input) }\end{array}$ & $\begin{array}{c}\text { Overall } \\
\text { efficiency } \\
\text { percent }\end{array}$ \\
\hline $\begin{array}{l}\text { Back-pressure } \\
\text { steam turbine }\end{array}$ & $4.0-14.3$ & $14-28$ & $84-94$ \\
\hline $\begin{array}{l}\text { Extraction- } \\
\text { condensing steam } \\
\text { turbine }\end{array}$ & $2.0-10.0$ & $22-40$ & $60-80$ \\
\hline Gas turbine & $1.3-2.0$ & $24-35$ & $70-85$ \\
\hline Combined cycle & $1.0-1.7$ & $34-40$ & $69-83$ \\
\hline $\begin{array}{l}\text { Reciprocating } \\
\text { engine }\end{array}$ & $1.2-2.5$ & $33-53$ & $75-85$ \\
\hline
\end{tabular}

Source: (E. C. B., 2007)

\section{(b)Quality of the heat energy required}

Pressure and temperature got from the CHP system is one of the determining factors in the selection of a CHP.Different applications requires different temperatures and pressures, for instance; a cement plant may require thermal energy of around $1400^{\circ} \mathrm{C}$ while a sugar mill will require about $120^{\circ} \mathrm{C}$ of thermal energy. It is important to choose a CHP depending on the thermal energy required.

\section{(c)Fuel availability}

Most of the CHP systems can easily be rejected since they cannot work with the available fuel source. Sugar factories for instance have bagasse as the input fuel in the boilers and hence steam turbines will be most viable in such a system with well-designed boilers. The steam generated as condensate can be used in the process house and the electricity generated can be used to drive the mills as well. In this case, the bagasse is the waste from sugar milling which are then used constructively. A rice mill will also use the a steam turbine since its husks can burn readily in a boiler and heat generated used for paddy drying while power generated used in mechanical milling. 


\section{Types of Prime Movers}

In identifying the right type of the combined heat and power technology, it is important to understand working principles of different available prime movers and the fuel types they use. This helps in reducing the production cost since most industries produce waste materials which can be used as fuel saving on the added cost of buying fuel and reducing the cost of waste disposal (Department of Energy and Climate, 2008). The commonly used types of the prime movers include:-

Steam turbines-Requires high pressure steams to operate. The steam can either be produced in the boiler or heat recovery steam generator. In this system, the steam enters into a turbine and causes the rotation of the turbine shaft whose mechanical output is converted to electricity by the generator. The steam exiting the turbine is used in thermal processes requiring heat as shown on figure 2.

Figure 2: Schematics of Steam turbine working principle.

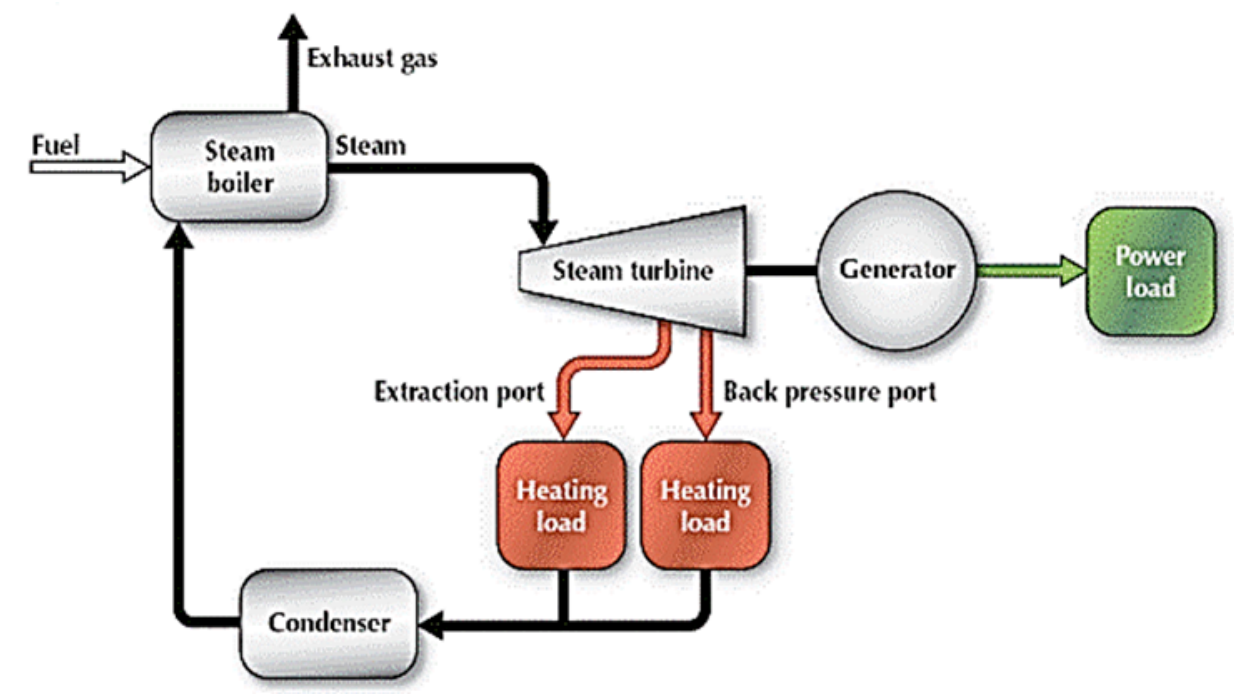

Source: (RETScreen International)

Gas turbines - It has a compressor which sucks air and compresses it to high pressure. The pressurised air then meets with injected fuel in the combustor where the fuel burns to produce a gas with high velocity and pressure which impinges on the turbine blades to drive the turbine shaft. The rotor's mechanical energy is then converted into electrical energy by the generator. The exhaust gas from the turbine goes to the heat recovery steam generator for heating load. The process summary is as shown on figure 3. Can use natural gas, high grade oils and synthesis gas. 
Figure 3: Schematics of gas turbine working principle

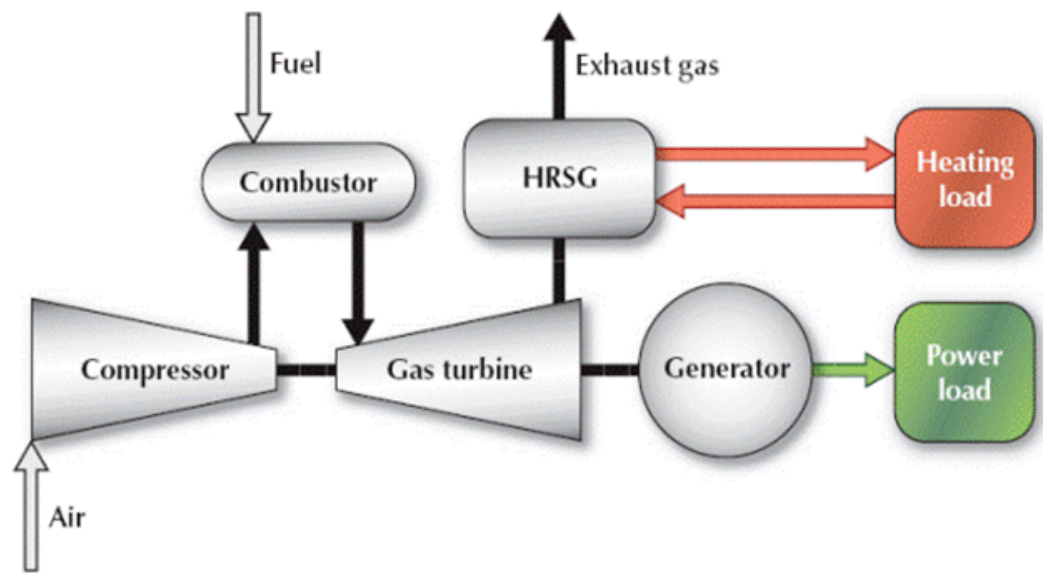

Source: (RETScreen International).

Gas turbine - combined cycle -In this system, there is compression of purified air in the compressor which is then mixed with the natural gas and ignited in the combustor. In the combustor, the air expands and gets pressurized at a high velocity which impinges on the turbine blade causing rotation of the turbine shaft. Since turbine blades are attached to a shaft, the shaft rotation is used to produce electricity in the generator. The exhaust gas from the turbine is then used to generate steam in the second stage via heat exchanger. The steam generated is used to drive another steam turbine and the condensate steam from the turbine used for heating loads. Has a demerit of only using natural gas, synthesis gas and high grade oils. Figure 4 summarizes the process.

Figure 4: Schematics of gas turbine - combined cycle working principle.

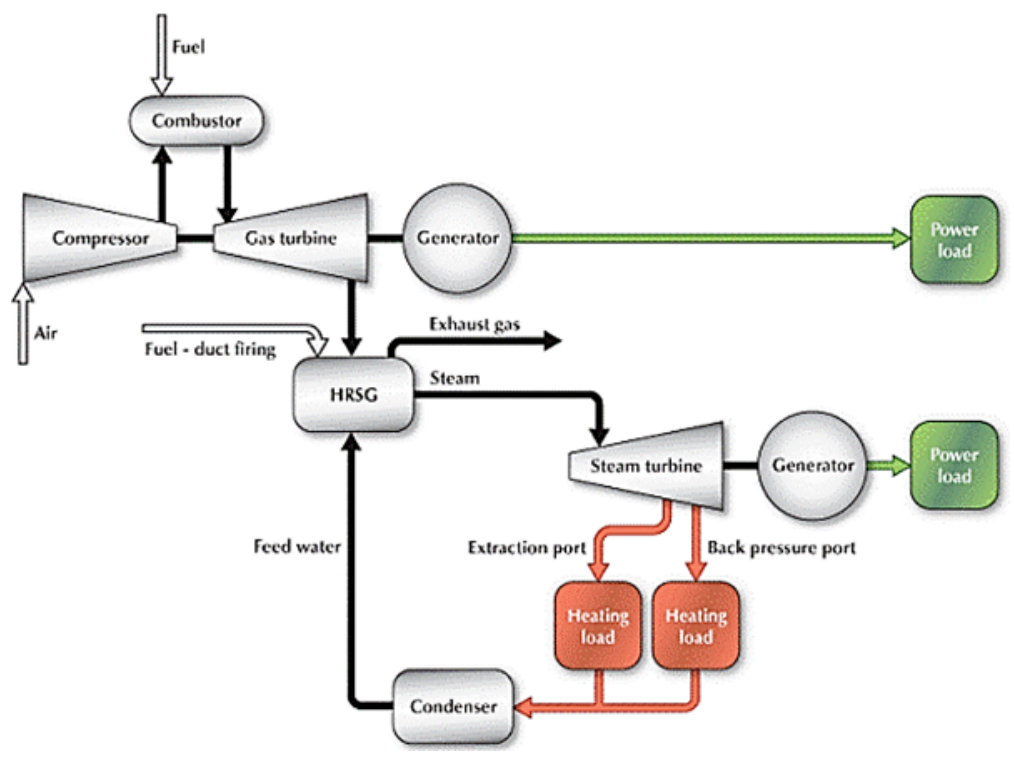

Source: (RETScreen International)

Reciprocating engine-In this process, the cycle begins by intake of air due to the vacuum created in the cylinder chamber when crank shaft pulls the piston downwards. Both fuel and air moves into the cylinder at the same time. The fuel 
and air is then compressed as the piston moves up and as the piston just approaches the top position, spark ignition occurs to the compressed air. The power of the hot expanded gases forces the piston down with force driving the crank shaft which generates electricity via a generator. The final stroke in the cycle then occurs when the piston moves upward and the hot exhaust gases exit via an open valve to heat recovery steam generator where heat recovered is used to provide thermal energy. This process occurs repeatedly almost 100 times per minute. System process is as shown on figure 5 .

Figure 5: Schematics of Reciprocating engine heat and power system

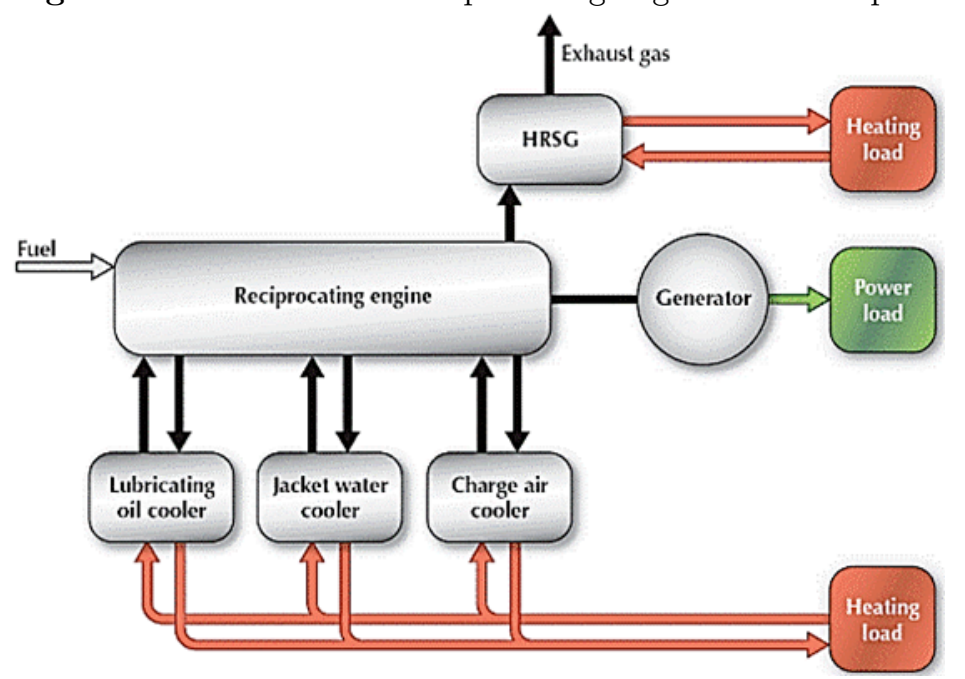

Source :( RETScreen International).

Fuel Cells - It generates electricity through chemical reaction of two substances e.g. oxygen and hydrogen. It electrochemically oxidises the fuel and generates both electricity and heat. The process can either be accelerated with a transition metal as a catalyst or acidic solution but requires no catalyst when it operates at a temperature above $600^{\circ} \mathrm{C}(\mathrm{EP} \mathrm{UK}, 2012)$. Figure 5 indicates the process set up. 
Figure 5: Schematics of Fuel Cells working process

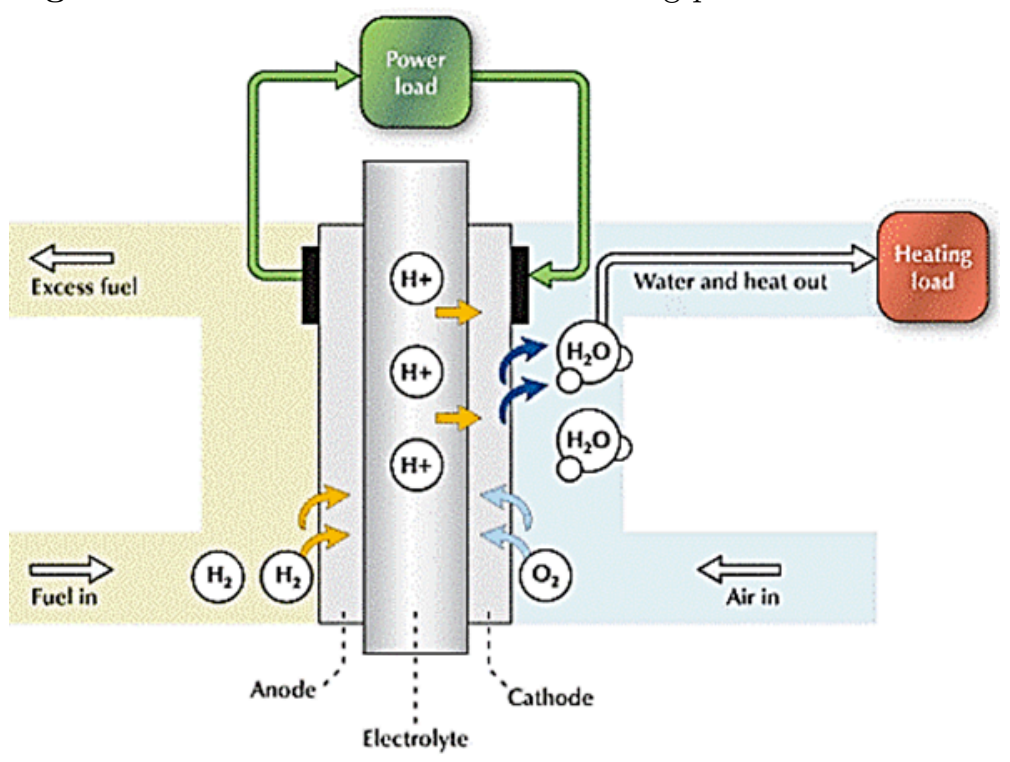

Source: (RETScreen International)

\section{Application of CHP}

Due to the economic standards and high efficiency of the Combined Heat and Power, this technology has become widely used. Applications include:-

Steam turbines- Applied in situations where fuels used are not expensive especially in industries and institutions. The fuels used are either by-products from the plant or fuels bought at relatively cheaper price. The fuels include: Byproducts such as wood chip, bagasse, coal and other biomass solid wastes. The steam produced from the boiler can either be extracted directly to be used or the exhaust steam from the turbine is used directly for heating demand (USEPA, 2015). Other plant sections benefits from electricity produced by the generator connected to the steam turbine. The steam turbines can drive the industrial electric motors, process pumps, refrigeration chillers and air compressor. When the steam turbine is operated at a single speed, it drives an electric generator while if it operates at a range of speed, it drives a refrigeration compressor (E.C Training guide)

Fuel Cells-The application depends on the type of fuel cell since different fuel cells gives different temperature outputs. For CHP applications requiring thermal products of low pressure steam and hot water, Low temperature fuel cells are applied while for high pressure steam applications, high temperature fuel cells will be needed (E.C Training guide).It is used in both commercial and residential applications to provide both heat and power. It has a credit of giving high efficiency over a very wide load profile with very low emissions. It is used for the space heating and potable water heating processes. It provides both power and thermal energy to supermarkets, restaurants and refrigerated ware houses (USEPA, 2015). 
Reciprocating internal combustion engines-The CHP application is majorly used where there is low pressure steam or hot water demand. More practicable where the engine power output is regulated depending on the power demand of the facility (E.C Training guide). It is used in institutions such as universities, hospitals, water treatment facilities, industrial facilities, commercial facilities and residential buildings to provide both power and heat. Provides thermal loads such as hot water requirements and space heating. This is indication that it has wide applications depending on the demand (USEPA, 2015).

Gas turbines-Are cost effective for industrial and commercial applications having base load electric demand of more than 5MW.Pocess high quality thermal output and hence they are applied in the district heating systems. Any wasted heat is recovered in the heat recovery steam generator(HRSG) which generates low or high pressure steam (E.C Training guide). Since gas turbines have very high temperature exhausts, they are used to generate both high temperature and pressure steam of around 1200 psi and $482^{\circ} \mathrm{C}$ respectively. Example of industrial application is a chemical plant having $25 \mathrm{MW}$ gas cycle turbine which supplies simple base load to that plant and recovering the heat from the exhaust to generate steam to run the processes in the plant. An example of institutional or commercial application of this system is where a college or university campus having $4.5 \mathrm{MW}$ simple-cycle gas turbine uses it to meet their thermal and electrical needs. In this case, averagely 8MW thermal steam of $150-400$ psi steam or hot water can be produced in the unfired heat recovery steam generator and distributed to the thermal loop for space heating in the campus during winter or for single effect absorption chillers for cooling when it is time for summer (USEPA, 2015). 
Table 3: Summary of applications of the combined heat and power

\begin{tabular}{|c|c|c|c|}
\hline Feature & CHP-Industrial & $\begin{array}{l}\text { CHP- } \\
\text { Commercial/institutional }\end{array}$ & District heating \\
\hline $\begin{array}{l}\text { Type of } \\
\text { Customers }\end{array}$ & $\begin{array}{l}\text { Heavy processing(Food, } \\
\text { textile, timber, minerals, pulp } \\
\text { and paper, metallurgy, } \\
\text { chemical coke, ovens, glass, } \\
\text { furnaces, oil refining }\end{array}$ & $\begin{array}{l}\text { Agricultural operations, Light } \\
\text { manufacturing, Large urban } \\
\text { office buildings, hotels, } \\
\text { hospitals }\end{array}$ & $\begin{array}{l}\text { All buildings with heating } \\
\text { demands within reach of heat } \\
\text { demand such as office } \\
\text { buildings, campuses, industry } \\
\text { airports }\end{array}$ \\
\hline $\begin{array}{l}\text { Required } \\
\text { temperature level }\end{array}$ & High & Low to Medium & Low to medium \\
\hline Fuel source & $\begin{array}{l}\text { Solid or gaseous fuels, Waste } \\
\text { gases from industrial } \\
\text { processes(blast furnace gases, } \\
\text { Coke oven waste gases, } \\
\text { liquids) }\end{array}$ & Liquid or gaseous fuels & $\begin{array}{l}\text { Any fuel for both commercial } \\
\text { and industrial/institutional }\end{array}$ \\
\hline $\begin{array}{l}\text { Type of prime } \\
\text { mover }\end{array}$ & $\begin{array}{l}\text { Steam turbine, Combined } \\
\text { cycle, Reciprocating engine, } \\
\text { Gas turbine, }\end{array}$ & $\begin{array}{l}\text { Reciprocating engine (spark } \\
\text { ignition), Fuel cells, Sterling } \\
\text { engines, micro-turbines. }\end{array}$ & $\begin{array}{l}\text { Steam turbines, gas turbine, } \\
\text { Combined cycle gas turbines, } \\
\text { Waste incineration }\end{array}$ \\
\hline $\begin{array}{l}\text { Typical system } \\
\text { size }\end{array}$ & 1-500MWe & $1 \mathrm{KWe}-10 \mathrm{MWe}$ & Any size \\
\hline $\begin{array}{l}\text { Load patterns of } \\
\text { heat or electricity }\end{array}$ & User and process dependent & User dependent & $\begin{array}{l}\text { Daily and seasonal } \\
\text { fluctuations reduced by load } \\
\text { management }\end{array}$ \\
\hline
\end{tabular}

Source: IEA, 2008

\section{Kenyan case study on cogeneration economics}

To compare the most economical choice between a gas turbine based cogeneration system and an alternative whereby electrical power is bought from the grid and thermal energy provided by steam produced in the plant from natural gas fired boiler (E. C. B., 2007)

\section{Plan A of gas turbine based cogeneration system}

Parameters

Gas turbine generator capacity

Yearly Plant Operating hours

Load factor of the plant (PLF)

Gas turbine supplier's standard heat rate

Unfired output steam

Temperature of the steam

Pressure of the Steam

Enthalpy of the steam

Type of the fuel used (Natural gas)

Fuel Calorific value

Price of the gas
Value $3500 \mathrm{Kw}$

$8100 \mathrm{hrs}$

$89 \%$

$3024.23 \mathrm{kCa} / \mathrm{kWh}$

$12 \mathrm{TPH}$

$210^{0} \mathrm{C}$

$9.5 \mathrm{~kg} / \mathrm{cm}^{2}$

$692.23 \mathrm{kCal} / \mathrm{kg}$

$9800 \mathrm{kCal} / \mathrm{sm}^{3}$

Ksh.3470/1000 sm ${ }^{3}$ 
Estimated yearly cost of capital + maintenance + Operation charges $=$ Ksh.29.81million

\section{Evaluation of the power and steam cost of the cogeneration plant}

Estimation of the power generation of the plant at a load factor (PLF) $89 \%$

$=$ Plant Load Factor $\mathrm{x}$ Capacity of the plant $\mathrm{x}$ yearly plant's operating hrs

$=(89 / 100) \times 3500 \times 8100) \mathrm{kWh} /$ year, $=252.32 \times 10^{5} \mathrm{kWh} /$ year

Total heat input for the calculated power generation

$=$ Estimated power generation $(\mathrm{kWh}) \mathrm{x}$ heat rate $(\mathrm{kCal} / \mathrm{kWh})$

$=\left(252.32 \times 10^{5} \times 3024.23\right) \mathrm{kCa}$

$=763058.59 \times 10^{5} \mathrm{kCa}$

Quantity of the natural gas needed per year

$=($ Total heat input / Natural gas Calorific Value),

$=\left(763058.59 \times 10^{5} / 9800\right) \mathrm{sm}^{3}$

$=77.86 \times 10^{5} \mathrm{sm}^{3}$

Fuel Cost per year $=$ Yearly gas consumption $\left(\mathrm{sm}^{3}\right) \mathrm{x}$ Price of the gas $\left(\mathrm{Ksh} / 1000 \mathrm{sm}^{3}\right)$

$$
=\mathrm{Ksh} .\left\{\left(77.86 \times 10^{5} \times 3470\right) / 1000\right\}
$$

$=$ Ksh.27.02 million

Estimated yearly cost of capital + maintenance + Operation charges $=$ Ksh.29.81million

Total yearly cost of power from the cogeneration plant

$=$ Fuel cost per year + Yearly cost of capital + maintenance + operation charges

$=$ Ksh. $(27.02+29.81)$ million, $=$ Ksh.56.83 million

Total Cost of power $(\mathrm{Ksh} / \mathrm{kWh})$

$=$ (Total yearly cost of power from the cogeneration plant/Yearly power generation)

$=\left(56.83 \times 10^{6} / 25.232 \times 10^{6}\right) \mathrm{Ksh} / \mathrm{kWh}$

$=\mathrm{Ksh} .2 .25 / \mathrm{kWh}$

Plan B of buying electrical power from the grid and producing thermal energy from the plant using natural gas fired boiler

Parameters

Average cost of the electric power from the natural grid

Total Capital investment for the $12 \mathrm{TPH}, 9.5 \mathrm{~kg} / \mathrm{cm}^{2}, 210^{0} \mathrm{C}$

Natural gas fired boilers

plus its auxiliaries:

\section{Value}

$\mathrm{Ksh} \cdot 3.75 / \mathrm{kWh}$
$\mathrm{kg} / \mathrm{cm}^{2}, 210^{0} \mathrm{C}$

Ksh.14.92 million 


\section{Evaluation of the cost of power from the grid and the steam from the plant's gas fired boiler}

\section{Cost of power using national grid}

At a plant Load Factor of $89 \%$, the power generated from initial calculation

$$
=252.32 \times 10^{5} \mathrm{kWh} / \text { year }
$$

Power cost from the national grid for $252.32 \times 10^{5} \mathrm{kWh} /$ year

$=$ Expected Power Generation $\mathrm{x}$ Cost of electric power from the grid.

$=\left(252.32 \times 10^{5} \mathrm{kWh} \times \mathrm{Ksh} .3 .75 / \mathrm{kWh}\right),=$ Ksh. 94.62 million $/$ year

\section{Cost of the fuel for the steam using a separate boiler}

Heat output of $12 \mathrm{TPH}$ steam per year

$$
\begin{aligned}
& =\text { Quantity of Steam x Enthalpy x Hours of Operation /Year } \\
& =(12 \times 1000 \times 692.23 \times 8100) \mathrm{kCa},=672847.56 \times 10^{5} \mathrm{kCal}
\end{aligned}
$$

Required heat input to generate $12 \mathrm{TPH}$ steam per year at $89 \%$ efficiency

$=($ Heat output of $12 \mathrm{TPH}$ steam per year/Boiler efficiency)

$=(672847.56 \times 105 / 0.89) \mathrm{kCal},=756008.49 \times 10^{5} \mathrm{kCa} /$ year

Quantity of the natural gas per year $=($ Heat Input $/$ Natural gas calorific value $)$

$$
\begin{aligned}
& =\left(756008.49 \times 10^{5} \mathrm{kCa} / 9800 \mathrm{kCal} / \mathrm{sm}^{3}\right) \\
& =77.14 \times 10^{5} \mathrm{sm}^{3} / \text { year }
\end{aligned}
$$

Fuel Cost per year $=$ Yearly gas consumption $\left(\mathrm{sm}^{3}\right) \mathrm{x}$ Price of the gas $\left(\mathrm{Ksh} / 1000 \mathrm{sm}^{3}\right)$

$$
\begin{aligned}
& =\mathrm{Ksh} .\left\{\left(77.14 \times 10^{5} \times 3470\right) / 1000\right\} \\
& =\text { Ksh.26.77 million/year }
\end{aligned}
$$

Plan B total cost $=$ Power cost from the national grid $/$ year + Fuel Cost per year

$$
=\text { Ksh. }(94.62+26.77) \text { million, }=\text { Ksh.121.39 million }
$$

Total cost of plan A. Ksh.56.83 million.

Total cost of plan B. Ksh.121.39 million

Cost difference $(\mathrm{B}-\mathrm{A})$ Ksh. 64.56 million

The above results shows that plan B is more expensive than plan A since it incurs additional cost of Ksh. 64.56 million due to added cost of separate boiler construction for steam production. It is therefore economical to have a gas turbine cogeneration system than buying electricity from national grid with separate natural gas fired boiler managed by the plant.

\section{CHP advantages and disadvantages}

Advantages

- Improvement of Energy efficiency (figure 1) and cost reduction. It can recover heat loss and turn it into usable energy.

- It saves the environment due to the less gaseous emissions-it helps in significant reduction of $\mathrm{SO}_{\mathrm{X}}, \mathrm{NO}_{\mathrm{X}}$ and $\mathrm{CO}_{2}$.

It is reliable and gives quality power-CHP has no vulnerability of power out rages at the same time reduces dependency on electric utility. Both thermal and electrical energy can be varied depending on the need. 
Disadvantages

- Only suitable where there is demand of both electricity and heating.

- The technology is sufficiently not sustainable if it is based on the fossil fuels.

- It requires that heating and electricity demand should remain fairly constant.

- It can experience high cost of maintenance.

\section{Conclusion}

CHP is therefore one of the best energy alternatives with higher efficiency compared to the conventional generation. CHP utilises less fuel to generate same energy as that of conventional generation which utilises more fuel to generate same amount of energy. This helps to reduce the greenhouse gas emissions into the atmosphere. CHP has very wide range of cost effective industrial applications. When cost analysis is done, CHP has less cost compared to alternative of buying power from grid and producing the heat using natural gas. The choice of a CHP depends on finance available, site demands in terms of power, heat, environmental compliance to the surrounding and fuel available to run the CHP. Depending on the type of fuel available, a particular CHP can be applied to meet the power and heat demands in different industrial applications.

\section{References}

Environmental Protection UK.2012.Combined Heat and Power: Air Quality guidelines for Local Authorities. [Online].[Accessed on 05/04/2015].Available on: http://www.iaqm.co.uk/text/guidance/epuk/chp_guidance.pdf

Department of Energy and Climate.2008. CHP Technology: A detailed guide for CHP developers Part 2. [Online].[Accessed on 06/04/2015].Available on:

https://www.gov.uk/government/publications/combined-heat-and-power-chp-technology

RETScreen International. [Online].[Accessed on 06/04/2015].Available on: http://www.retscreen.net/ang/steam_turbine_schematic.php

Code, E. C. B. (2007). Bureau of Energy Efficiency. Ministry of Power, Government of India.

Code, E. C. B.2007.Bureau of Energy Efficiency: Ministry of Power, Government of India [Online]. [Accessed on 04/04/2015]. Available at:

http://www.beeindia.in/energy_managers_auditors/documents/guide_books/2Ch7.pdf

U.S Environmental Protection Agency.2013. Guide to Using Combined Heat and Power for Enhancing Reliability and Resiliency in Buildings. [Online]. [Accessed on 04/04/2015].Available at: http://portal.hud.gov/hudportal/documents/huddoc?id=CHPSept2013.pdf

U.S. Environmental Protection Agency.2008.CHP Partnership.[online][Accessed on 04/04/2015] Available at www.epa.gov/chp

US. Environmental Protection Agency.2015.Catalogue of CHP technologies-Steam turbines.[Online].[Accessed on 08/04/2015].Available on: http://www.epa.gov/chp/technologies.html

European Commission: Training Guide on Combined Heat and Power System.[Online].[Assessed on 08/04/2015].Available on: http://www.cres.gr/kape/education/3.CHP_en_small.pdf

International Energy Agency.2008.Combined Heat and Power: Evaluating the benefits of greater global investment.[Online].[Assessed on 08/04/2015].Available on:

https://www.iea.org/publications/freepublications/publication/chp_report.pdf 
Vasebi, A., Fesanghary, M., \& Bathaee, S. M. T. 2007. Combined heat and power economic dispatch by harmony search algorithm. International Journal of Electrical Power \& Energy Systems. 29(10),pp.713-719.

Song, Y. H., Chou, C. S., \& Stonham, T. J. 1999. Combined heat and power economic dispatch by improved ant colony search algorithm. Electric Power Systems Research. 52(2), pp. 115-121.

Sanaye, S., Meybodi, M. A., \& Shokrollahi, S. (2008). Selecting the prime movers and nominal powers in combined heat and power systems. Applied Thermal Engineering. 28(10), pp.1177-1188. 